\title{
INSTITUTIONAL CONVERGENCE OF BULGARIA TO THE EUROZONE COUNTRIES
}

\author{
Maria Marikina ${ }^{1}$ \\ e-mail:mmarikina@unwe.bg
}

\begin{abstract}
Institutions are one of the main factors for the economic growth and development of any economy. And insofar as development is defined as a set of economic and institutional factors, the reduction of differences in the development of individual countries and regions naturally leads us to the institutional convergence, which is the object of study. When researching the convergence of Bulgaria to the EU countries and more closely to the Eurozone, many questions arise about whether there is institutional convergence and how it can be revealed. This is the subject of analysis presented in the study. The thesis presented here is that it is possible to consider institutional convergence for Bulgaria with the countries of the Euro zone, represented by qualitative and quantitative indicators, which, however, is unstable. The methodology is based on the understanding of institutional convergence as the converging of economic and political institutions, and given the fact that they are different for each of the economies; a comparative analysis is used to study the convergence as a whole. For this purpose, the analysis of institutional quality and comparative analysis uses the main indicators of the World Bank-Worldwide Governance Indicators (WGI) and Ease of Doing Business Indicator. The results of the pre-selected criteria give grounds to find those of the observed indicators, which reveal improvement and respectively converging in the direction of institutional convergence of Bulgaria with the countries from the EU area.
\end{abstract}

Key words: institutions, institutional quality, institutional convergence

JEL: D02, O43, O47

\section{Introduction to the subject area}

The definition of institutional convergence is seen as the converging of economic and political institutions, the "rules of the game", the regulations existing in the integration society and determining the behavior of economic entities. Institutional convergence implies the presence of compatibility of institutions in terms of structures and their functioning and its meaning is sought in the fact that it is a strong prerequisite for the convergence of economies in the creation of a space, region, and union. The aim of this type of cohesion is to

\footnotetext{
${ }^{1}$ Assoc. Prof., PhD, Department of Economics, University of National and World Economy
} 
create a basis for faster growth and therefore for economic prosperity through the institutional adjustment of individual economies in line with the developed ones.

"The level of institutional convergence from a theoretical and practical point of view can be considered at international, regional and national level, and everywhere the most important is the impact on the nature, evolution, quality of institutions and their capabilities. To examine converging in general, comparative economic analyzes of economic integration are used to identify the evolution of certain subjects at the appropriate level against others that are considered to perform best or at an average level. In this type of analysis at the respective level, the way in which the factors involved in a given process act to reduce the differences between the analyzed subjects must be found. The reduction of inequalities creates preconditions for the convergence of values in certain performance indicators and ensures the reduction of gaps within the respective level of development of the respective subjects" (Marikina, 2019).

For the purposes of the study, the focus is within the European Union, more closely on the Euro zone countries and the national economy, as it is highly valid that institutional convergence is the result of two different but often one-way processes determining the nature of regional economic integration. The first type of process is widespread in the EU and this is the so-called Ex ante convergence related to one of the most important institutions - the state and its policy aimed at the development of weaker institutions and their harmonization with the more developed in the respective regions. The other type, Ex post convergence, is rather the result of the spontaneous interaction of economic agents and the inflow of goods, services and capital between countries, as well as competition between countries for mobile factors of production.

Our interest in convergence in general and institutional convergence in particular is due to the economic significance of the phenomenon. This is because institutional convergence can play the role of both a necessary condition and a result of economic integration. In the first case, without reaching the required level of convergence, it is practically impossible to further deepen integration; for example, if economic interests are divergent in reaching a consensus on the implementation of one measure or another, then integration will involve significant costs. It is this problem facing extremely heterogeneous groups and without the existence of a powerful center (institution) to exercise economic coercion, it would be difficult to overcome the emerging contradictions. In the second case, no less important are the institutional differences in countries with different decision-making mechanisms, where it is difficult to understand the logic of the other "players in the game" and whose mistrust would create problems in trust for integration. Regardless of which of the cases is considered, the participants pursue the reduction of disparities and the elimination of the forces that cause 
them. Institutional convergence presupposes the existence of institutional compatibility in terms of structures and functioning, and the meaning for Bulgaria is institutional improvement and convergence in accordance with the developed economies in the EU and the Euro zone.

\section{Theoretical research on the institutional convergence}

The study of the processes of economic convergence is closely dependent on the quality and completeness of data and statistical information. Their compilation, reporting and processing, especially as regards a country's financial statistics, are not subject to political interference. The countries that are members of an integration structure, through a certain mechanism, consider the quality and completeness of their statistical information, and as a matter of paramount importance in its collection is the ability to ensure the use of an appropriate system of checks and control in the statistical sphere. These standards are important, with the aim of strengthening the independence, integrity and accountability of national statistical institutes. Furthermore, confidence in the quality of government financial statistics is strengthened and proof is established of the right direction of convergence. However, given the nature of the "institution" category and the logic sought in institutional convergence, it is difficult to find and provide statistical information of the type of public finance that would accurately help to study the problem.

Research in the field of institutional convergence is new and in most cases is in the context of measuring holdings in macroeconomic terms and degree of integration. For example, researchers from the Institute of Applied Sciences in Barcelona López-Tamayo J., Raul Ramos R. and Suriñach J. (2014) are trying to design and build a combined indicator to measure the macroeconomic, social and institutional dimensions of countries. In their opinion the index would allow for not only comparing the relative situation of the countries but also their evolutionary development. To illustrate the usefulness of the index, they analyze the effects of the European Neighborhood Policy in the EU's neighboring countries over the last decade. The results show that the EPP (European People's Party), for example, has different effects according to what is being considered, and that the evolution of neighboring countries is quite heterogeneous, taking into account their previous institutional and economic results. From a political perspective, these results reinforce the validity of bilateral action plans, which characterize political forces that take into account the different starting points and specific characteristics of each neighboring country.

Again in this context, J. Tomayo, R. Ramos and J. Suriñach report that if the study of economic cohesion usually uses a measurement of gross domestic product (GDP) per capita, institutional and social surveys Cohesion within the 
EU are relatively scarce. In fact, the authors believe that the main limitation for analysis at EU level is the availability and comparability of data, which is why most researchers focus on country-specific research. An example is the study by Liargovas, G. and Fotopoulos G. (2009), "Socioeconomic Indicators for Analyzing Convergence: The Case of Greece: 1960 - 2004", which analyzes socioeconomic cohesion between Greek regions. Remarkable exceptions are those of Rodriguez-Pose A. and Tselios V., of 2013, who analyze the trends of convergence in the EU in terms of social welfare of the countries and Savoia, A. and Sen, K. (2012), who consider cohesion in the institutions.

The research of J. L. Tomayo, R. Ramos and J. Suriñach contributes to the study of institutional convergence in terms of accepting the advantages of a recently developed composite indicator (Lopez-Tamayo et al., 2014), which enables them to analyze convergence in institutional, social and macroeconomic conditions across a wide range of countries, including the 28 EU Member States. Currently, the scientific literature expands these views not only in economic but also in social and institutional dimensions. In fact, the methodology developed by Lopez-Tamayo (Lopez-Tamayo et al., 2014) adds to the growing scientific efforts to overcome the shortcomings of one-dimensional approaches such as those that use mainly GDP, and to move to approaches and measurement based on a wide range of variables, or based on a multidimensional index. One such example is the United Human Development Index. Even though it has been widely criticized in the scientific literature (see, for example, Wu et al., 2014), this combined indicator, the authors believe, will allow analyzing the comparative situation between the countries examined along different dimensions. The broader perspective in building the index allows them to focus on many different issues using a homogeneous data set. They believe that such a general index from an economic point of view or aspect can be used to analyze the pros and cons of a particular policy that seeks to attract foreign direct investment, while providing for the examination of the impact on institutional and social aspects. (e.g. related to the functioning of the labor market after the entry of foreign investors in the country). The second aspect of their study is related to the fact that the analysis covers the period from 1995 to 2015 . This period allows them to consider the impact of the recession in different dimensions, analyzing the impact of the business cycle on convergence trends comparing the two sub periods - before both during and after the crisis. The authors believe that despite the convergence processes predicted by the neoclassical model, short-term conditions may affect long-term convergence through different channels. For example, during the expansion phase and thanks to the improvement of public finances, the processes will be accompanied by an increase in investment for development, which will lead to an improvement in the economy in the short term. There will be a positive effect in terms of increasing long-term productivity, increasing the speed of convergence. 
The main assumption, however, is that the convergence process is non-linear and countries with different short-term conditions may deviate from the long-term convergence trend.

The scarcity of institutional convergence research has also been relatively reduced by research by German economists Nina Schönfelder and Helmut Wagner. Initially, Schönfelder's thoughts were on the EU institutions and the possibility of institutional convergence within its framework (Schönfelder, 2017), and later research, together with those of $\mathrm{H}$. Wagner, are in-depth and in the direction of options for its measurement (Schönfelder, Wagner, 2019). They apply the statistical concepts of $\sigma$-convergence and unconditional $\beta$-convergence to institutional development in several groups of EU countries according to their degree of economic integration (respectively membership in the Euro zone). They use two sets of indicators to measure institutional development: first, global governance indicators; and second, the indicators for regulating the OECD product market and for doing business with the World Bank. The authors confirm the institutional $\beta$-convergence within the EU and its candidate countries, which is guided mainly by the new Member States, the acceding, the applicant and the potential candidate countries. However, Euro zone countries converge only in product market and business regulation, not in governance. In fact, the authors provide evidence of a $\beta$-deviation in the rule for the first twelve Euro zone Member States. In terms of $\sigma$-convergence, the results are much vaguer. Only the EU, including applicants for EU membership, reduces disparities between countries in all aspects of institutional development.

E. Raluca and P. Prisecaru use a similar approach to that of Nina Schönfelder and Helmut Wagner in the study of institutional cohesion. The same World Bank indicators apply, but the interest here is focused on answering the question of what model of institutional cohesion should be sought (Raluca, 2014; Prisecaru, 2008). The model, they argue, is likely to be linked to a process by which governments are elected, controlled and replaced, and further to the ability to formulate and implement effective and sensible policies for citizens and the state. Another approach to the study of institutional convergence is applied by M. Gruševaja and T. Pusch (Gruševaja, Pusch, 2015) in their attempt to avoid the lack of empirical data and the specifics of the institutions. In 2015, their study was presented as an attempt to provide a unified approach to institutional cohesion in CEE countries in terms of EU norms (related to the accomplishments of the EU) and related developments. The study consists of two complementary parts. First, a cluster analysis of the institutional conditions of the CEE countries is conducted on the basis of the transition indicators developed and published by the European Bank for Reconstruction and Development (EBRD). The authors believe that since institutional variables usually show inertia, the analysis should be based on dura- 
tion of several years, and the appropriate selection is associated with significant changes in institutional settings relative to European norms, e.g. dates of association agreements, dates of accession to the EU and the like. Secondly, special attention is paid to the relationship between the institutional environment and economic growth, which differs significantly between CEE countries. For the empirical link between institutional convergence with EU norms and growth, non-parametric methods are used, which allow the accounting of short time series and the relatively small number of countries. The authors conclude that, except in the first years of transition, there is little evidence of institutional convergence between CEE countries, and since 1999 the EBRD's transition indicators have not been indicative of growth.

On institutional convergence, a number of researchers, mainly from Romania and the Czech Republic, report that in conventional economic theory the institutional dimension of economies has long been neglected. A new paradigm is allowed, in which the idea is increasingly developing that institutions were part of the category of important factors that can determine the development of nations, economic growth or decline, as the institutional factor stimulates or blocks economic and social mechanisms (Iancu, 2009). Given the positive role that the institutional system should play in CEE, it is concluded that institutional cohesion should become not only an object of in-depth study, but also a starting point and a basis for compliance of the structure and requirements of the EU institutional system - an important criterion for the accession of the countries to the EU and their integration into the Economic and Monetary Union (EMU).

The changes that have taken place in the economies of CEE in recent decades, and the mistakes made by some of these countries during such changes, reveal how important the institutional system really is (Gruševaja, Pusch, 2015). And if there are institutional differences, or more importantly - an institutional gap, it would cause a real disaster in terms of economic and social life of the countries that began the transition without the consistent functioning of the institutions in the new context. The role of institutions and their importance is recognized in the new paradigm, but the main reason for not solving the problems of institutional cohesion comes from the difficulty of measuring processes and expressing them in quantitative indicators, in the reduced ability to aggregate indicators as reliable, significant, rigorous, and synthetic ones.

"Outside the European space, institutional cohesion is very limited and difficult to study General research on convergence is generally available, albeit insufficient, and that on institutional cohesion is still very scarce. For example, the Russian scientist Igor Pelipas (Pelipas, 2017) tries to analyze in one the real, nominal and institutional convergence of the countries of the Eurasian Economic Union. Its new methodology makes it possible to determine the existence of com- 
mon and "club" convergence. His analysis shows that in the countries of this union there are different types of convergence, and his conclusions are that there is a common convergence for all countries except Kazakhstan, club real convergence, common nominal convergence and concludes that there is a common institutional convergence of this whole base.

Outside of Europe and integration processes, there is almost no research on institutional convergence. Only three more significant documents in this direction can be found. This is first of all a study by A. Savoia and K. Sen (Savoia, Sen, 2012), which focuses on the $\beta$-convergence of institutions in several different institutional measures included in the Economic Freedom Report in the world. Cohesion tests have been performed using parts of the Economic Freedom Index, but there has been no report on the coefficients. The second paper is by $\mathrm{N}$. Elert and D. Halvarsson (Elert, Halvarsson, 2012), who use the entire Economic Freedom Index as a measure of institutions and find evidence of convergence using a panel data approach. However, they do not control other determinants of change in economic freedom than the original value or change in time. And the latest work is by C. Boudreaux and R. Holcombe (Boudreaux, Holcombe, 2015), who view institutional convergence from 1970 to 2010 as an unbalanced panel of a group of countries" (Marikina, 2019). All studies, if need be summarized, are evidence of interest in the issue of institutional convergence. This subject area is new, the studies may be more or less successful in terms of institutional convergence, but they are proof of the economic significance of the phenomenon.

\section{Institutional quality as a basis for convergence}

Each economy is characterized by specific institutions as a set of fundamental political, social and legal rules that form the basis for production, exchange, distribution and consumption in the economy. Through the prism of institutional convergence, this must be linked to the meaning of converging - through institutional improvement and bringing individual economies in line with the developed ones, a basis must be created for faster growth and accordingly for economic prosperity. Given this, for each of the economies it is necessary to make an assessment in a way that includes the laws, the rights of individuals, services, high-quality government regulation, etc., i.e. the quality itself, which reflects the institutional specifics. That is why the scientific quality is the institutional quality and the possibility to find criteria for it.

Institutional quality is a concept that encompasses institutions and concerns the law, individual rights, high-quality state regulation and the provision of services. According to IMF experts, "the quality of institutions means the quality of contract performance, property rights, shareholder protection and the like" (IMF, 2003). In order to examine and analyze institutional quality, several criteria 
must be met (Popescu, 2012). The first criterion for assessing institutional quality is universality (Kasper, Streit, 1998). It presupposes general, open, abstract, social rules, or, as Hayek puts it, rules that must be "applicable to an unknown and indeterminate number of people and circumstances" (Hayek, 1937, p. 50). The second criterion stems from the main function of the institutions, the reduction of transaction costs and uncertainty in human interactions, thus ensuring a high level of security and stability in economic and social relations. In this regard, institutions should be characterized by reliability and stability, be transparent and easily recognizable. Another criterion is the adaptability or ability of institutions to anticipate change and offer socio-economic incentives to agents in order to facilitate adaptation to new socio-economic conditions.

Institutional quality is particularly important because it and economic development are interdependent and "impulsive" to each other in the long run. It is assumed that countries with high institutional quality are more successful in applying advanced technologies, for example, and have increased their productivity since the beginning of the millennium. It can be hypothesized that institutional development is the best indicator of structural development and long-term wealth creation for a nation. Economic growth is known to be key to determining a nation's short-term trajectory, regardless of its origin, but institutional development determines whether short-term positive outcomes are sustainable in the long run. High-quality institutions will not protect the economy from the next economic crisis in a market economy. However they increase the chances that a society copes with and recovers from such a crisis and continues on its long-term trajectory of progress. Therefore, in the first place, the quality of the institutional environment should be seen as a basic requirement for economic success and long-term progress. Second, institutional quality consists of a wide range of factors, some of which are difficult to measure. Therefore, the analysis made in terms of the quality of the institutions is in order to identify the evolution of certain entities at the appropriate level against others that are considered to perform best or at an average level. The justification is presented through a single database of publicly available data that is as objective and representative as possible. It can be found in the literature selection of indicators for a similar purpose, as in Easterly, W., King, R., Levine, R., and Rebelo, S. (1992) and more recent studies by Kuncic (2014) and Fabro and Aixalá (2013), Bruinshoofd (2016).

For the purpose of this piece of research, institutional quality consists of seven variables available in the World Bank database, which are the six indicators of management - Worldwide Governance Indicators (WGI) and the indicator of Ease of Doing Business. Institutional quality will be built on an annual basis, first with management indicators, so that institutional improvements or deteriorations over time can also be tracked, and with the addition of the Ease of Doing Business 
indicator, the quality of processes and administrative work after those of WGI. The period covers the years 2000 to 2018, and the following seven key indicators will be specifically assessed:

1) Voice and Accountability: capturing the extent to which the country's citizens participate in the election of government and follow the policy pursued, as well as freedom of expression, association and media freedom.

2) Political stability and the absence of violence: minimizing the likelihood of the government destabilizing through unconstitutional or violent means, including terrorism.

3) Government effectiveness: achieving quality of public services, capacity of state institutions, independence from political pressure, quality of formulated policies, thus creating a favorable context for private investment.

4) Regulatory quality: the ability of the government to formulate sound policies and regulations that allow and encourage the development of the private sector, thus establishing uniform rules for economic engagement.

5) Rule of Law: reflects the possibility of respecting the rule of law, taking into account in particular the quality of the implementation of contracts, property rights, the application of police and court rules.

6) Control on corruption: the stronger the control over corruption, the more economic success is a function of effort and competence, not of connections and bribes.

7) Ease of Doing Business: covers a number of aspects that determine the extent to which the regulatory environment is conducive to business. These aspects concern starting a business, registering property, obtaining credit, protecting investors, paying taxes, cross-border trade, enforcing contracts, insolvency decisions and more.

\section{Empirical and comparative analysis of the quality of institutions}

In the analysis of institutional quality, the key indicators used are an appropriate basis for empirical analysis and comparison with other EU countries. The first six indicators are presented in percentile or country rank among all others included in the World Bank survey (penultimate column of the tables below). It should be borne in mind that the 0th corresponds to the lowest rank and the $100^{\text {th }}$ to the highest. In the seventh indicator (Ease of Doing Business), the values are from 0 to $100 \%$, as for the closest, i.e. best performance is assumed to be $100 \%$, and the observed period is for the years in which data are available from 2006 to 2019. According to World bank, "Doing Business presents results for two aggregate measures: the Ease of Doing Business score and the Ease of Doing Business ranking, which is based on the Ease of Doing Business score. The Ease of Doing Business ranking compares economies with one another; the Ease of Doing 
Business scores benchmark economies with respect to regulatory best practice, showing the proximity to the best regulatory performance on each Doing Business indicator" (World bank, 2020b).

Following the data from the beginning of 2000, the middle of the period 2010, until 2018 for each of the variables, a fairly accurate assessment can be made for the individual indicators. They can be an appropriate tool for assessing Bulgaria on a comparative basis with other countries for the period from 2000 to 2018. The first six indicators are set out in tables that include Bulgaria and the Euro zone countries from the beginning of the period -2000 , the middle -2010 and the last year - 2018, for which data are available. The seventh indicator - Ease of Doing Business - in accordance with the available data and period, is presented in tabular and figurative form. Along with the empirical analysis, possible solutions and appropriate policies for rapprochement of Bulgaria with the Euro zone countries on each of the indicators for the quality of the institutional environment are proposed. At the end of the study, the relevant conclusions about the institutional convergence of Bulgaria are reached.

\section{Voice and Accountability}

Voice and Accountability is the first indicator by which the quality of institutions is assessed. According to the data of the World Bank, presented in Table 1, the result for our country cannot be considered as a success during the analyzed period. There is a deterioration compared to the initial year from 62.19 in 2000 to 59.11 for 2018 , despite some improvement in mid-2010 values of 64.45. These results are considered unsatisfactory in terms of the extent to which the country's citizens participate in the choice of government, their ability to follow the policy, as well as in expression, association and media freedom.

Table 1: Voice and Accountability

\begin{tabular}{|c|l|c|c|c|}
\hline \multicolumn{1}{|c|}{ Indicator } & \multicolumn{1}{|c|}{ Country } & Year & Perc.rang & Stand.er. \\
\hline 1 & \multicolumn{1}{|c|}{2} & 3 & 4 & 5 \\
\hline Voice and Accountability & Austria & 2000 & 90.05 & 0.20 \\
\hline & Austria & 2010 & 95.26 & 0.15 \\
\hline & Austria & 2018 & 93.10 & 0.15 \\
\hline & Belgium & 2000 & 92.54 & 0.20 \\
\hline & Belgium & 2010 & 94.31 & 0.15 \\
\hline & Belgium & 2018 & 94.09 & 0.15 \\
\hline & Bulgaria & 2000 & 62.19 & 0.18 \\
\hline & Bulgaria & 2010 & 64.45 & 0.13 \\
\hline & Bulgaria & 2018 & 59.11 & 0.13 \\
\hline
\end{tabular}




\section{Continued}

\begin{tabular}{|c|c|c|c|c|}
\hline 1 & 2 & 3 & 4 & 5 \\
\hline & Cyprus & 2000 & 80.60 & 0.21 \\
\hline & Cyprus & 2010 & 79.15 & 0.15 \\
\hline & Cyprus & 2018 & 80.79 & 0.16 \\
\hline & Estonia & 2000 & 77.11 & 0.20 \\
\hline & Estonia & 2010 & 83.41 & 0.13 \\
\hline & Estonia & 2018 & 89.66 & 0.13 \\
\hline & Finland & 2000 & 99.50 & 0.20 \\
\hline & Finland & 2010 & 96.68 & 0,15 \\
\hline & Finland & 2018 & 98.52 & 0.15 \\
\hline & France & 2000 & 86.07 & 0.20 \\
\hline & France & 2010 & 90.05 & 0.14 \\
\hline & France & 2018 & 88.18 & 0.14 \\
\hline & Germany & 2000 & 89.55 & 0.20 \\
\hline & Germany & 2010 & 92.42 & 0.14 \\
\hline & Germany & 2018 & 95.07 & 0.14 \\
\hline & Greece & 2000 & 78.61 & 0.20 \\
\hline & Greece & 2010 & 74.41 & 0.13 \\
\hline & Greece & 2018 & 75.37 & 0.15 \\
\hline & Ireland & 2000 & 93.03 & 0.20 \\
\hline & Ireland & 2010 & 93.36 & 0.15 \\
\hline & Ireland & 2018 & 92.12 & 0.16 \\
\hline & Italy & 2000 & 79.60 & 0.20 \\
\hline & Italy & 2010 & 75.83 & 0.12 \\
\hline & Italy & 2018 & 81.77 & 0.14 \\
\hline & Latvia & 2000 & 70.15 & 0.20 \\
\hline & Latvia & 2010 & 72.04 & 0.13 \\
\hline & Latvia & 2018 & 74.88 & 0.14 \\
\hline & Lithuania & 2000 & 73.63 & 0.20 \\
\hline & Lithuania & 2010 & 75.36 & 0.13 \\
\hline & Lithuania & 2018 & 77.83 & 0.14 \\
\hline & Luxembourg & 2000 & 95.02 & 0.24 \\
\hline & Luxembourg & 2010 & 98.58 & 0.16 \\
\hline & Luxembourg & 2018 & 96.55 & 0.17 \\
\hline & Malta & 2000 & 86.57 & 0.25 \\
\hline & Malta & 2010 & 88.63 & 0.15 \\
\hline
\end{tabular}


Continued

\begin{tabular}{|l|l|c|c|c|}
\hline & \multicolumn{1}{|c|}{2} & 3 & 4 & 5 \\
\hline & Malta & 2018 & 83.74 & 0.17 \\
\hline & Netherlands & 2000 & 98.01 & 0.20 \\
\hline & Netherlands & 2010 & 96.21 & 0.15 \\
\hline & Netherlands & 2018 & 97.04 & 0.15 \\
\hline & Portugal & 2000 & 92.04 & 0.20 \\
\hline & Portugal & 2010 & 83.89 & 0.14 \\
\hline & Portugal & 2018 & 88.67 & 0.14 \\
\hline & Slovak Republic & 2000 & 72.64 & 0.20 \\
\hline & Slovak Republic & 2010 & 74.88 & 0.13 \\
\hline & Slovak Republic & 2018 & 76.85 & 0.14 \\
\hline & Slovenia & 2000 & 83.08 & 0.20 \\
\hline & Slovenia & 2010 & 81.52 & 0.13 \\
\hline & Slovenia & 2018 & 79.31 & 0.13 \\
\hline & Spain & 2000 & 88.56 & 0.20 \\
\hline & Spain & 2010 & 85.31 & 0.14 \\
\hline & Spain & 2018 & 82.76 & 0.14 \\
\hline
\end{tabular}

Source: World Bank (2020c) and own calculations

According to the data presented on the indicator of Voice and Accountability, it can also be seen that at the beginning of the period the best performing countries are Finland, the Netherlands, Luxembourg, Belgium and Austria, while worst performing ones are Slovenia, Lithuania, Latvia and Italy. Bulgaria, compared to other countries, shows a significantly lower value of 62.19 , even compared to the weakest in the table. At the end of 2018, countries such as Belgium, Luxembourg and Austria improved their results, Finland and the Netherlands worsened them, Germany registered a significant improvement compared to the initial period, and countries that initially revealed lower performance such as Lithuania, Latvia and Italy showed an increase in the reported values. At the end of the same period, Bulgaria deteriorated its performance and reported an even lower value than 59.11. For our country this can be seen as a sign of distancing from the countries of the Euro zone. In order to reduce and overcome the weaknesses in this criterion, the institutions in Bulgaria need to focus their efforts on overcoming racism, intolerance and discrimination, violence against women and domestic violence, and media restrictions. It is advisable from the point of view of reducing differences to proceed to political and cultural change in the way minority groups are treated and represented in Bulgaria, where hate speech, discrimination and hostility towards Roma and persons belonging to other minority groups are 
worrying. In such logic, the government in the country should change the policy and initiate improvement of legislation, and raise public awareness of the need to strengthen the protection of victims of violence against women and domestic violence. Particular attention must be paid to promoting gender equality.

Another aspect of this indicator is essential for the possible gradual reduction of disparities with the Euro zone countries, namely freedom of expression. It is provided for in human rights documents and refers to the right to receive or transmit information, the right to remain silent, and the right to form one's own opinions. These freedoms are well recognized in EU countries, the problem is to what extent the governments of each country are trying to control the media and/or access to the media in order to influence the masses and gain their support, or to stop the opposition from doing so. Highly controlled media, however, damage social awareness, knowledge of world events, reliable analysis, as well as information about the state of the economy, political developments and social facts. For Bulgaria, media freedom has deteriorated due to a number of aggregate factors, including non-transparent media ownership and financing, harassment of journalists, use of defamation and political influence. By emphasizing the importance of a free and pluralistic media for the proper functioning of democracy, the authorities should create a favorable environment for freedom of expression, in particular by preventing excessive concentration of media property, repealing criminal provisions against defamation offenses and others, and to punish all perpetrators of threats and attacks against journalists. There is a need to improve the professional protection and working conditions of journalists and to make the composition and mandate of the Electronic Media Council more independent and effective.

\section{Political stability and absence of violence}

The second indicator for the observed period from 2000 to 2018 reveals a lack of improvement. For Bulgaria, on the one hand, we observe a strong dependence of the political stability and adaptability of the government on the change of the political structures and the government in the country, and on the other hand, on the changes in the economy. In general, a slight deterioration in this parameter prevails for the observed period (Table 2). The data for 2000 with a starting value of 61.9 are quite reasonable, an improvement in the rating during the following year, when our country was preparing for full membership in the EU, by varying the values corresponding to sensitivity as a reaction to the changes of governments in Bulgaria, until 2018, when there is a slight decline in the rating compared to the initial year of the study period. 
Table 2: Political stability and absence of violence

\begin{tabular}{|c|c|c|c|c|}
\hline Indicator & Country & Year & Perc.rang & Stand.er. \\
\hline 1 & 2 & 3 & 4 & 5 \\
\hline Political Stability and & Austria & 2000 & 76.1 & 0.3 \\
\hline \multirow[t]{33}{*}{ Absence of Violence } & Austria & 2010 & 89.1 & 0.2 \\
\hline & Austria & 2018 & 80.9 & 0.2 \\
\hline & Belgium & 2000 & 83.6 & 0.3 \\
\hline & Belgium & 2010 & 74.4 & 0.2 \\
\hline & Belgium & 2018 & 59.5 & 0.2 \\
\hline & Bulgaria & 2000 & 61.9 & 0.3 \\
\hline & Bulgaria & 2010 & 57.8 & 0.2 \\
\hline & Bulgaria & 2018 & 60.5 & 0.2 \\
\hline & Cyprus & 2000 & 68.8 & 0.3 \\
\hline & Cyprus & 2010 & 61.6 & 0.2 \\
\hline & Cyprus & 2018 & 64.8 & 0.2 \\
\hline & Estonia & 2000 & 77.8 & 0.3 \\
\hline & Estonia & 2010 & 67.8 & 0.2 \\
\hline & Estonia & 2018 & 66.2 & 0.2 \\
\hline & Finland & 2000 & 99.5 & 0.3 \\
\hline & Finland & 2010 & 97.2 & 0.2 \\
\hline & Finland & 2018 & 81.9 & 0.2 \\
\hline & France & 2000 & 74.1 & 0.3 \\
\hline & France & 2010 & 68.7 & 0.2 \\
\hline & France & 2018 & 51.9 & 0.2 \\
\hline & Germany & 2000 & 95.2 & 0.3 \\
\hline & Germany & 2010 & 73.5 & 0.2 \\
\hline & Germany & 2018 & 66.7 & 0.2 \\
\hline & Greece & 2000 & 75.1 & 0.3 \\
\hline & Greece & 2010 & 40.8 & 0.2 \\
\hline & Greece & 2018 & 50 & 0.2 \\
\hline & Ireland & 2000 & 97.9 & 0.3 \\
\hline & Ireland & 2010 & 84.8 & 0.2 \\
\hline & Ireland & 2018 & 86.2 & 0.2 \\
\hline & Italy & 2000 & 78.8 & 0.3 \\
\hline & Italy & 2010 & 62.6 & 0.2 \\
\hline & Italy & 2018 & 57.6 & 0.2 \\
\hline & Latvia & 2000 & 63.5 & 0.3 \\
\hline
\end{tabular}


Continued

\begin{tabular}{|c|c|c|c|c|}
\hline 1 & 2 & 3 & 4 & 5 \\
\hline & Latvia & 2010 & 64.5 & 0.2 \\
\hline & Latvia & 2018 & 61 & 0.2 \\
\hline & Lithuania & 2000 & 64 & 0.3 \\
\hline & Lithuania & 2010 & 70.6 & 0.2 \\
\hline & Lithuania & 2018 & 72.9 & 0.2 \\
\hline & Luxembourg & 2000 & 98.9 & 0.4 \\
\hline & Luxembourg & 2010 & 99.1 & 0.3 \\
\hline & Luxembourg & 2018 & 96.2 & 0.2 \\
\hline & Malta & 2000 & 98.4 & 0.4 \\
\hline & Malta & 2010 & 91.9 & 0.2 \\
\hline & Malta & 2018 & 93.8 & 0.2 \\
\hline & Netherlands & 2000 & 100 & 0.3 \\
\hline & Netherlands & 2010 & 81.5 & 0.2 \\
\hline & Netherlands & 2018 & 78.1 & 0.2 \\
\hline & Portugal & 2000 & 94.7 & 0.3 \\
\hline & Portugal & 2010 & 71.1 & 0.2 \\
\hline & Portugal & 2018 & 89.5 & 0.2 \\
\hline & Slovak Republic & 2000 & 70.9 & 0.3 \\
\hline & Slovak Republic & 2010 & 86.7 & 0.2 \\
\hline & Slovak Republic & 2018 & 72.4 & 0.2 \\
\hline & Slovenia & 2000 & 77.2 & 0.3 \\
\hline & Slovenia & 2010 & 77.3 & 0.2 \\
\hline & Slovenia & 2018 & 80 & 0.2 \\
\hline & Spain & 2000 & 65.6 & 0.3 \\
\hline & Spain & 2010 & 33.6 & 0.2 \\
\hline & Spain & 2018 & 55.2 & 0.2 \\
\hline
\end{tabular}

Source: World Bank (2020c) and own calculations

The data presented in Table 2 reveal a fairly complex dynamics within the Euro zone. At the beginning of the period, in 2000, countries such as the Netherlands, with an absolute value of 100, Finland, Germany, Luxembourg and Malta showed strong performance on this indicator. The weaker performance is for Spain, Latvia, Lithuania and Cyprus. Bulgaria in the initial period is the country that is after this second group, with a value of 61.9. At the end of the period, in 2018, Lithuania and Cyprus revealed an improvement in this indicator, while in Latvia and Spain there was a deterioration, in Bulgaria as well, although slight. The 
group of countries with a deteriorating indicator also includes France and Greece, the data of which are worse than those for Bulgaria. This dynamics in the period from 2000 to 2018 for our country cannot be regarded categorically as a sign of distance or rapprochement from the Euro zone countries. Bulgaria's participation as a member of the EU directs our policy towards the principles of freedom, democracy and solidarity is practically related to serious positives, because our country receives full and equal status with the most developed and established countries in the world. At the same time, however, Bulgaria retains the vast majority of its sovereign powers: foreign policy and defense, fiscal policy, social policy, education and science, penal policy, etc. In these areas, key decisions are taken at the national level, with EU powers still more coordinating and ancillary. In this sense, although the EU's influence on the political processes in our country is significant, it is far from being the only explanatory factor for what has been happening in recent years. This is also demonstrated by the differences in the political dynamics between our country and other EU countries, as well as by the various main problems they face. Bulgaria faced two basic problems in the period 2000 - 2019: to create an environment for equalizing economic development compared to other member states and to tackle widespread corruption. With regard to both problems, the achievements are significant, but they still remain below the level of the Euro zone countries. Despite some progress with regard to political stability, Bulgaria has not improved its position on the rule of law and still comes in last in the EU according to this indicator. Our country is lagging behind in terms of planning, policy making and coordination. Despite some improvements, evidence-based policy making continues to suffer from limited administrative capacity and a lack of data. In this context, the reduction of differences with the countries of the Euro zone is yet to be overcome.

The absence of violence in the country is associated with freedom from harassment, threats and torture. According to this indicator, in Bulgaria there are constitutional guarantees of freedom from harassment, threats and torture and this freedom is largely respected in practice. The reports of the delegation of the European Committee for the Prevention of Torture and Inhuman or Degrading Treatment or Punishment at the Council of Europe, which regularly visits Bulgaria, can serve as proof of compliance with these requirements. Its activity is to review the measures taken by the Bulgarian authorities in response to the recommendations of previous visits to the Committee. The Committee accepts the measures taken by the Bulgarian authorities, while at the same time making some additional recommendations regarding safeguards against ill treatment in places of detention. 


\section{Government effectiveness}

Thirdly, in assessing the institutional quality - the effectiveness of the government, the results show that there is an improvement in the quality of public services, the capacity of state institutions, independence from political pressure, the quality of formulated policies (Raleva, Marikina, 2020). According to the data provided by the World Bank, if we compare the initial year 2000 and the end year 2018 of the observed period, it can be found that the effectiveness of government decisions is characterized by improvement and a value of 56.41 reaches 62.98 (Table 3).

Table 3: Government effectiveness

\begin{tabular}{|c|c|c|c|c|}
\hline Indicator & Country & Year & Perc.rang & Stand.er. \\
\hline & 1 & 2 & 3 & 4 \\
\hline \multirow[t]{26}{*}{ Government Effectiveness } & Austria & 2000 & 94.87 & 0.21 \\
\hline & Austria & 2010 & 97.13 & 0.23 \\
\hline & Austria & 2018 & 90.87 & 0.22 \\
\hline & Belgium & 2000 & 91.28 & 0.21 \\
\hline & Belgium & 2010 & 92.82 & 0.23 \\
\hline & Belgium & 2018 & 83.65 & 0.22 \\
\hline & Bulgaria & 2000 & 56.41 & 0.20 \\
\hline & Bulgaria & 2010 & 59.33 & 0.20 \\
\hline & Bulgaria & 2018 & 62.98 & 0.20 \\
\hline & Cyprus & 2000 & 85.13 & 0.25 \\
\hline & Cyprus & 2010 & 90.91 & 0.24 \\
\hline & Cyprus & 2018 & 77.88 & 0.22 \\
\hline & Estonia & 2000 & 76.92 & 0.20 \\
\hline & Estonia & 2010 & 82.30 & 0.22 \\
\hline & Estonia & 2018 & 84.62 & 0.21 \\
\hline & Finland & 2000 & 99.49 & 0.21 \\
\hline & Finland & 2010 & 99.52 & 0.23 \\
\hline & Finland & 2018 & 99.04 & 0.22 \\
\hline & France & 2000 & 90.77 & 0.21 \\
\hline & France & 2010 & 89.00 & 0.23 \\
\hline & France & 2018 & 91.83 & 0.22 \\
\hline & Germany & 2000 & 93.85 & 0.21 \\
\hline & Germany & 2010 & 92.34 & 0.23 \\
\hline & Germany & 2018 & 93.27 & 0.22 \\
\hline & Greece & 2000 & 74.36 & 0.21 \\
\hline & Greece & 2010 & 69.38 & 0.23 \\
\hline
\end{tabular}




\section{Continued}

\begin{tabular}{|c|c|c|c|c|}
\hline & 1 & 2 & 3 & 4 \\
\hline & Greece & 2018 & 65.87 & 0.22 \\
\hline & Ireland & 2000 & 89.74 & 0.21 \\
\hline & Ireland & 2010 & 87.08 & 0.23 \\
\hline & Ireland & 2018 & 89.90 & 0.22 \\
\hline & Italy & 2000 & 78.97 & 0.21 \\
\hline & Italy & 2010 & 66.99 & 0.23 \\
\hline & Italy & 2018 & 68.27 & 0.22 \\
\hline & Latvia & 2000 & 66.15 & 0.20 \\
\hline & Latvia & 2010 & 72.73 & 0.21 \\
\hline & Latvia & 2018 & 79.81 & 0.21 \\
\hline & Lithuania & 2000 & 62.05 & 0.20 \\
\hline & Lithuania & 2010 & 74.16 & 0.22 \\
\hline & Lithuania & 2018 & 80.77 & 0.21 \\
\hline & Luxembourg & 2000 & 96.92 & 0.24 \\
\hline & Luxembourg & 2010 & 94.26 & 0.24 \\
\hline & Luxembourg & 2018 & 95.67 & 0.22 \\
\hline & Malta & 2000 & 83.59 & 0.29 \\
\hline & Malta & 2010 & 83.73 & 0.24 \\
\hline & Malta & 2018 & 78.85 & 0.24 \\
\hline & Netherlands & 2000 & 98.97 & 0.21 \\
\hline & Netherlands & 2010 & 94.74 & 0.23 \\
\hline & Netherlands & 2018 & 96.63 & 0.22 \\
\hline & Portugal & 2000 & 82.56 & 0.21 \\
\hline & Portugal & 2010 & 80.38 & 0.23 \\
\hline & Portugal & 2018 & 86.54 & 0.22 \\
\hline & Slovak Republic & 2000 & 73.33 & 0.20 \\
\hline & Slovak Republic & 2010 & 76.08 & 0.22 \\
\hline & Slovak Republic & 2018 & 75.48 & 0.21 \\
\hline & Slovenia & 2000 & 77.95 & 0.19 \\
\hline & Slovenia & 2010 & 81.34 & 0.22 \\
\hline & Slovenia & 2018 & 83.17 & 0.21 \\
\hline & Spain & 2000 & 91.79 & 0.21 \\
\hline & Spain & 2010 & 78.95 & 0.23 \\
\hline & Spain & 2018 & 79.33 & 0.22 \\
\hline
\end{tabular}

Source: World Bank (2020c) and own calculations 
According to the data presented in Table 3 it can be established that at the beginning of the period - in 2000 - the best performing countries are Finland, the Netherlands, Luxembourg and Austria, and least of all Lithuania, Latvia, Slovakia and Slovenia. Bulgaria, compared to the Euro zone, again shows the lowest value of 56.4. At the end of 2018, the leading countries at the beginning of the period showed deteriorated values for the indicator, as did Austria, Belgium, the Netherlands and Luxembourg, and others in the same group did not report a change in practice, as in Finland and Germany. In the countries that initially revealed lower performance, in 2018 there is an increase in the reported values Slovenia, Slovakia, Lithuania and Latvia. At the end of the same period, Bulgaria improved its performance to 62.9, but still had the lowest values of all euro zone countries. Nevertheless this can be considered as a positive trend for our country and can be interpreted as a sign of rapprochement with the Euro zone countries. The established efficiency of the government and cohesion are due to the improvements in public administration and e-government, which largely depend on EU support. Despite the achievement of the key intermediate targets for 2018 set out in the Government's Good Governance Operational Program, however, the long delays and lack of capacity of some of the beneficiaries of key projects call into question the successful implementation of the reforms. Important projects such as the establishment of the national health information system, the introduction of the national electronic identification scheme and the new identity documents that provide electronic identification were delayed and progress in 2019 was insignificant. The updated strategy for the development of e-government and the action plan for 2019 - 2023 set out significant decisions. Nevertheless some key issues have not been sufficiently addressed, such as cyber security and critical infrastructure security. Some progress has been made with the provision of electronic services, in particular for businesses. At the same time, many electronic services remain limited and are mainly in the provision of information. The increase in the number of users of e-government services is indicative. The problems to be solved with e-government, which are still an obstacle to its functioning, are related to the insufficient modern legislation on the provision of specific services. E-government's sustainable development is significantly limited because of the difficulty that the public sector faces in attracting and retaining specialists in the field of information technology. Even though the provision of public services has been slightly improving, in terms of quality our country still differs from the Euro zone countries. Bulgaria is among the Member States with the lowest results in terms of quality and convenience of using public services. Improving the transparency of the public sector can be positively assessed as an indicator of government's effectiveness. 


\section{Regulatory quality}

In fourth place among the dimensions of institutional quality is the regulatory quality, which according to the World Bank data for Bulgaria has significantly improved. This means that for the period from 2000, when the value was 60.0 to 2018 with a value of 72.6, the government's ability to provide stable policies and regulations that allow and encourage the development of the private sector has been improving (Raleva, Marikina, 2020). Even in the first years following the global economic crisis, the institutions' reactions in this respect were quite adequate and a value of 74.16 was registered in 2010 (Table 4).

Table 4: Regulatory quality

\begin{tabular}{|c|c|c|c|c|}
\hline Indicator & Country & Year & Perc. rang & Stand.er. \\
\hline & 1 & 2 & 3 & 4 \\
\hline \multirow[t]{25}{*}{ Regulatory Qulity } & Austria & 2000 & 93.33 & 0.24 \\
\hline & Austria & 2010 & 92.34 & 0.24 \\
\hline & Austria & 2018 & 91.35 & 0.22 \\
\hline & Belgium & 2000 & 86.67 & 0.24 \\
\hline & Belgium & 2010 & 85.65 & 0.24 \\
\hline & Belgium & 2018 & 86.06 & 0.22 \\
\hline & Bulgaria & 2000 & 60.00 & 0.23 \\
\hline & Bulgaria & 2010 & 74.16 & 0.16 \\
\hline & Bulgaria & 2018 & 72.60 & 0.18 \\
\hline & Cyprus & 2000 & 84.10 & 0.32 \\
\hline & Cyprus & 2010 & 90.43 & 0.25 \\
\hline & Cyprus & 2018 & 81.25 & 0.25 \\
\hline & Estonia & 2000 & 88.72 & 0.23 \\
\hline & Estonia & 2010 & 88.52 & 0.18 \\
\hline & Estonia & 2018 & 91.83 & 0.20 \\
\hline & Finland & 2000 & 97.44 & 0.24 \\
\hline & Finland & 2010 & 99.04 & 0.24 \\
\hline & Finland & 2018 & 97.12 & 0.22 \\
\hline & France & 2000 & 80.51 & 0.24 \\
\hline & France & 2010 & 86.60 & 0.24 \\
\hline & France & 2018 & 83.65 & 0.22 \\
\hline & Germany & 2000 & 91.28 & 0.24 \\
\hline & Germany & 2010 & 93.78 & 0.24 \\
\hline & Germany & 2018 & 94.71 & 0.22 \\
\hline & Greece & 2000 & 77.95 & 0.24 \\
\hline
\end{tabular}




\section{Continued}

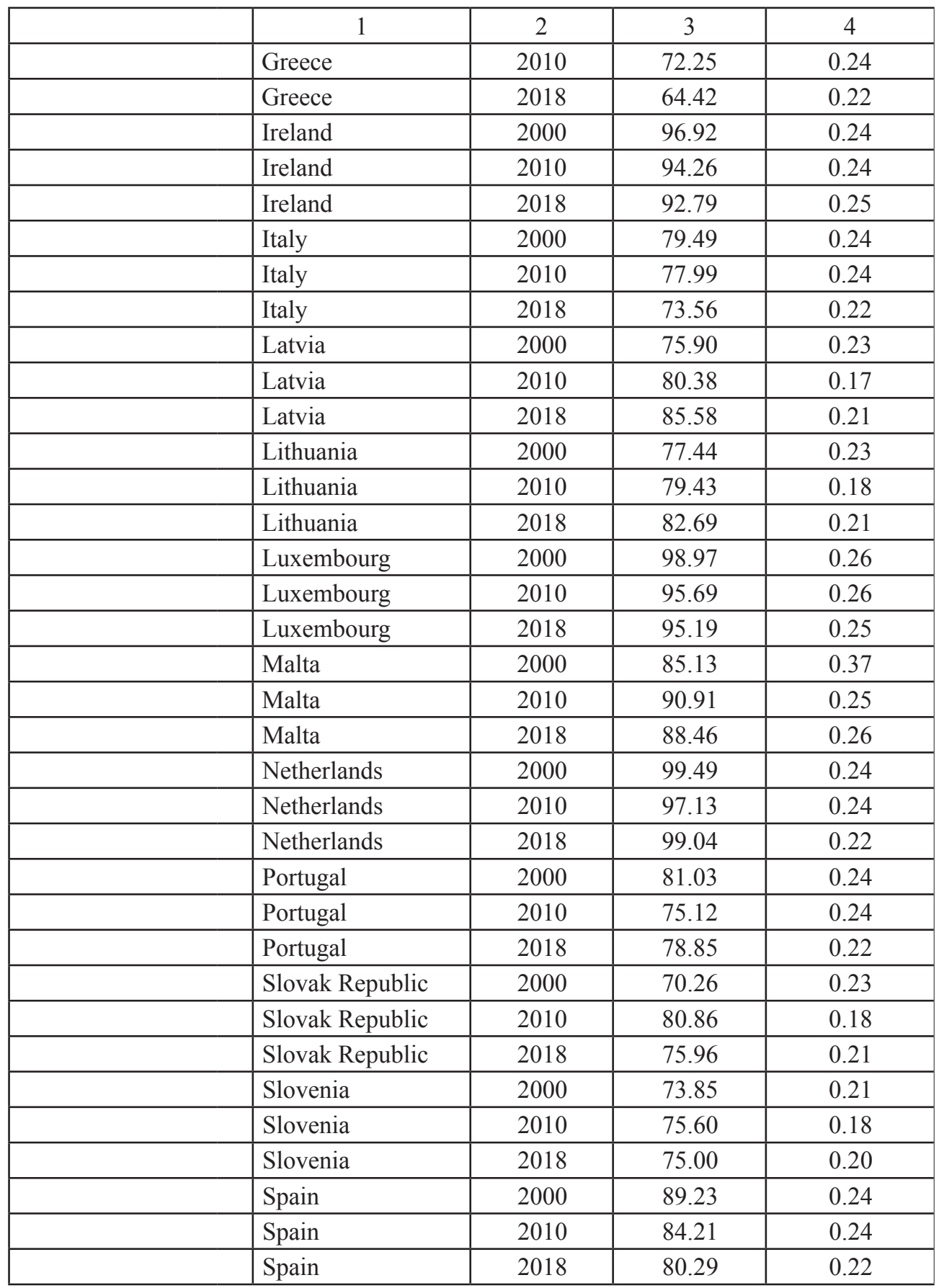

Source: World Bank (2020c) and own calculations 
According to the World Bank data, in terms of regulatory quality there was divergent dynamics in most of the Euro zone countries. At the beginning of the period, in 2000, the countries with the highest values were the Netherlands, Luxembourg, Finland and Ireland, while Slovakia, Greece, Italy and Latvia had the lowest values. At the end of the period under examination, in 2018 most of the Euro zone countries reported deterioration in the data, as did the first and second groups of countries: Ireland, Luxembourg, Greece, Austria and Italy. Approximately the same values remain in Finland and the Netherlands, while there is little improvement in Latvia and Slovakia. In 2018, given Bulgaria's approaching membership in the European Monetary Mechanism (ECM), a significant improvement of 72.6 was found in the value of the indicator. In this respect our country outperforms some of the Euro zone countries. This is a positive trend and can be seen as a sign of rapprochement with the Euro zone countries. Bulgaria's advantages in terms of regulatory quality, through which higher convergence with the Euro zone countries can be achieved, are identified in several indisputable ones as: financial stability - currency board until joining the Euro zone, NATO and EU membership, low 10-percent corporate tax in the EU, zero profit tax rate for investments in 152 municipalities with high unemployment (out of a total of 264 municipalities), increased depreciation rates (to $50 \%$ ) for investments in new machines, production equipment and apparatus; computers, peripherals and software, the use of a tax credit under the special procedure for charging VAT on imports for the implementation of investment projects over BGN 10 million, $5 \%$ tax on dividends, $10 \%$ "flat tax" on personal income, etc. It should also be noted that the administrative environment continues to improve $83 \%$ of all regimes proposed for relief have been abolished or eased, unnecessary or some regulatory regimes of the non-governmental sector have been eliminated, incentives have been introduced to encourage investment under the Investment Promotion Act and the Regulations for its implementation. The signs of cohesion are due to the pursuit of sound policies and regulations and of private sector promotion and to the rules of economic engagement. One of the governments' most important programs is indicative in this respect - the effectively implemented Innovation and competitiveness of Bulgaria until 2020. A new Program for Innovation and Competitiveness for $2021-2027$ (ARC) has been adopted, which is directly aimed at the implementation of industrial and innovation transformation and at achieving intelligent and sustainable growth of the Bulgarian economy.

\section{Rule of law}

According to the World Bank data for the period from 2000 to 2018, Bulgaria shows improvement in terms of the Rule of law indicator. During the initial year 2000 the value stood at 48.51 , rising to 53.10 in 2010 and reaching to 53.37 in 2018 (Table 5). 
Table 5: Rule of law

\begin{tabular}{|c|c|c|c|c|}
\hline Indicator & Country & Year & Perc.rang & Stand.er. \\
\hline & 1 & 2 & 3 & 4 \\
\hline \multirow[t]{34}{*}{ Rule of Law } & Austria & 2000 & 98.0 & 0.1 \\
\hline & Austria & 2010 & 96.2 & 0.1 \\
\hline & Austria & 2018 & 97.6 & 0.1 \\
\hline & Belgium & 2000 & 88.6 & 0.2 \\
\hline & Belgium & 2010 & 89.1 & 0.2 \\
\hline & Belgium & 2018 & 88.5 & 0.2 \\
\hline & Bulgaria & 2000 & 48.5 & 0.2 \\
\hline & Bulgaria & 2010 & 53.1 & 0.1 \\
\hline & Bulgaria & 2018 & 53.4 & 0.1 \\
\hline & Cyprus & 2000 & 83.7 & 0.2 \\
\hline & Cyprus & 2010 & 87.2 & 0.2 \\
\hline & Cyprus & 2018 & 76.0 & 0.2 \\
\hline & Estonia & 2000 & 72.3 & 0.2 \\
\hline & Estonia & 2010 & 85.3 & 0.1 \\
\hline & Estonia & 2018 & 86.5 & 0.1 \\
\hline & Finland & 2000 & 100.0 & 0.2 \\
\hline & Finland & 2010 & 100.0 & 0.2 \\
\hline & \begin{tabular}{|l|} 
Finland \\
\end{tabular} & 2018 & 100.0 & 0.2 \\
\hline & France & 2000 & 91.1 & 0.2 \\
\hline & France & 2010 & 90.5 & 0.2 \\
\hline & France & 2018 & 88.9 & 0.2 \\
\hline & Germany & 2000 & 93.6 & 0.2 \\
\hline & Germany & 2010 & 92.4 & 0.2 \\
\hline & Germany & 2018 & 91.3 & 0.2 \\
\hline & Greece & 2000 & 80.2 & 0.2 \\
\hline & Greece & 2010 & 67.3 & 0.2 \\
\hline & Greece & 2018 & 59.1 & 0.2 \\
\hline & Ireland & 2000 & 92.6 & 0.2 \\
\hline & Ireland & 2010 & 95.7 & 0.2 \\
\hline & Ireland & 2018 & 89.9 & 0.2 \\
\hline & Italy & 2000 & 77.2 & 0.2 \\
\hline & Italy & 2010 & 63.0 & 0.2 \\
\hline & Italy & 2018 & 61.5 & 0.2 \\
\hline & Latvia & 2000 & 57.9 & 0.2 \\
\hline
\end{tabular}


Continued

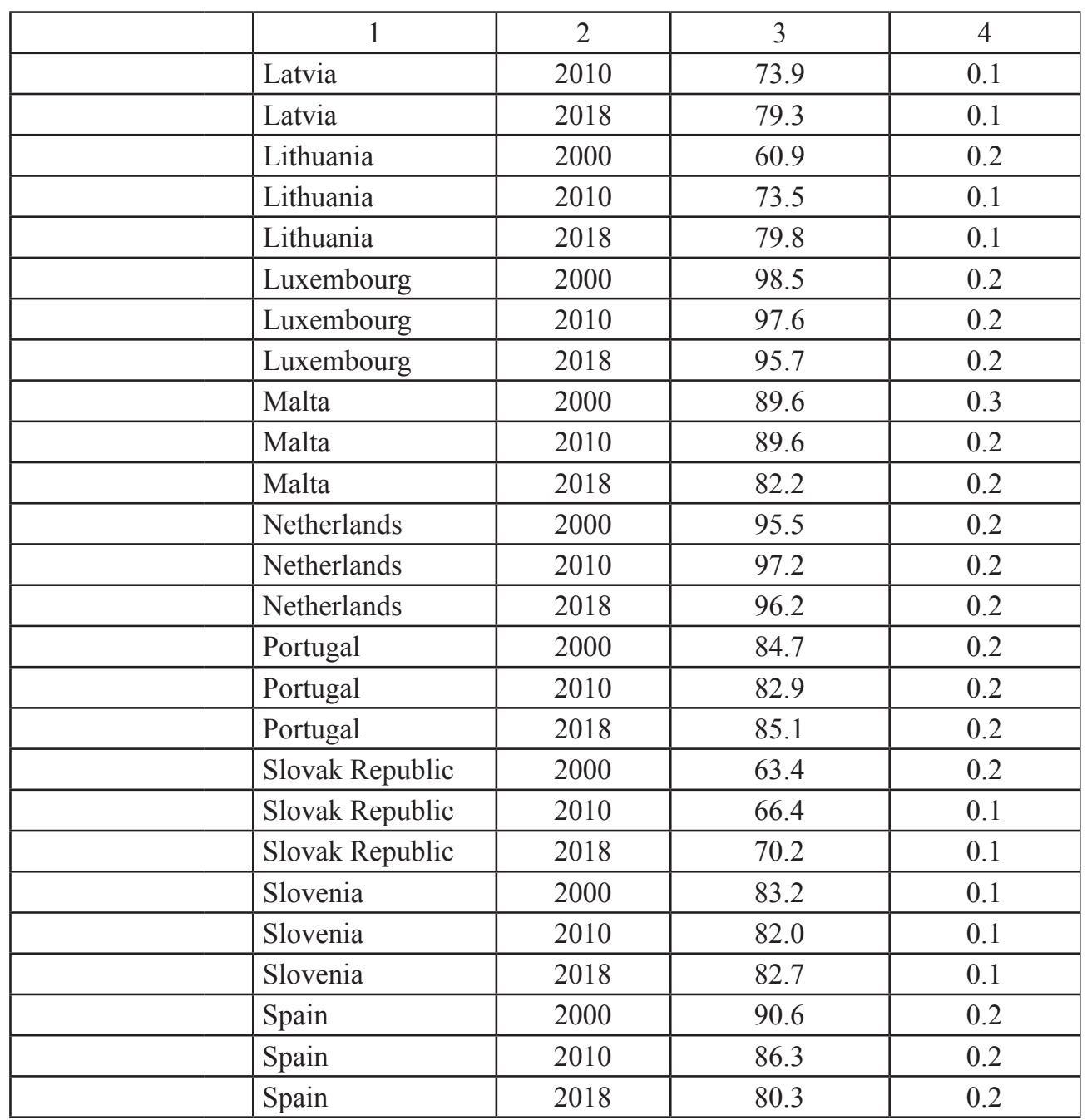

Source: World Bank (2020c) and own calculations

For the observed countries as a whole, the data in the table reveal heterogeneous dynamics. At the beginning of the study period, Finland had the strongest representation with an absolute value of 100.0, Austria, Ireland, the Netherlands and Germany are represented together with the weakest the countries of Eastern and Central Europe, namely Latvia, Lithuania, Slovakia, Slovenia and the older countries of the Euro zone - Greece. At the end of the period, in 2018 from the first group of countries Finland maintains its leadership with the same value, the Netherlands improves it, while in most countries the value in this indicator 
deteriorated. By contrast, the group of Eastern European countries is improving their values, including Bulgaria. Although these data for our country are well below those of the excellent-performing ones, the positive trend is a fact and can be interpreted as a sign of rapprochement with the Euro zone countries. The positive effects of this indicator, giving grounds to assume Bulgaria's observed convergence, are related to the further progress made in the reform efforts to improve the efficiency of the judiciary. In a progress report on the cooperation and verification mechanism for 2019 the European Commission noted that there were positive developments and further commitments to continue the reform. Specifically, the significant number of appointments of court presidents has been carried out without controversy, as well as the successful EU-funded project to strengthen the Inspectorate's capacity at the Supreme Judicial Council with regard to disciplinary proceedings. Positive developments in the legal and regulatory framework have been identified in the perceptions of citizens and businesses about the judiciary's independence, which continue to increase. The European Commission again made the assessment that Bulgaria had improved compared to the previous year, although the perception of independence were not very high yet. This is partly a reflection of fears of interference in the work of judges and pressure on them by economic interests, as well as by the government and individual politicians. There are positive dynamics in terms of perceptions of the independence of the judiciary and the criteria of the Sustainable Development Goals (SDGs) "Peace, Justice and Strong Institutions".

Regarding the quality of the application of the rules in the judiciary, the results are mixed. Again What becomes clear from the data provided by the EU's Information Board in the field of justice in 2020 is that there are some positive changes, such as further improvements in online access to published court decisions, promotion and encouragement of the use of alternative dispute resolution methods. Weaknesses are found in the ongoing gaps in the data presented, which do not allow for a comprehensive assessment of the overall efficiency of the judiciary. The courts generally function effectively, but there is no specific data on civil and commercial litigation at first and second instance.

\section{Control on corruption}

The ranking for the sixth indicator reveals changes in a negative aspect. In the beginning -2000 the value was 53.81 , followed by several years in which almost no significant change was observed. For 2010 the value stood at 53.3, followed by a steady negative trend that continued until 2018, dropping to 50.96 (Table 6). These data suggest that there is no agreement about the very understanding of anti-corruption measures and their implementation. 
Table 6: Control on corruption

\begin{tabular}{|c|c|c|c|c|}
\hline Indicator & Country & Year & Perc.rang & Stand.er. \\
\hline & 1 & 2 & 3 & 4 \\
\hline \multirow[t]{34}{*}{ Control on Corruption } & Austria & 2000 & 92.8 & 0.2 \\
\hline & Austria & 2010 & 91.9 & 0.1 \\
\hline & Austria & 2018 & 91.3 & 0.1 \\
\hline & \begin{tabular}{|l|} 
Belgium \\
\end{tabular} & 2000 & 90.9 & 0.2 \\
\hline & Belgium & 2010 & 91.0 & 0.2 \\
\hline & Belgium & 2018 & 90.4 & 0.1 \\
\hline & Bulgaria & 2000 & 53.8 & 0.2 \\
\hline & Bulgaria & 2010 & 53.3 & 0.1 \\
\hline & Bulgaria & 2018 & 50.9 & 0.1 \\
\hline & Cyprus & 2000 & 84.8 & 0.3 \\
\hline & \begin{tabular}{|l|} 
Cyprus \\
\end{tabular} & 2010 & 80.0 & 0.2 \\
\hline & \begin{tabular}{|l|} 
Cyprus \\
\end{tabular} & 2018 & 74.0 & 0.2 \\
\hline & \begin{tabular}{|l|} 
Estonia \\
\end{tabular} & 2000 & 79.2 & 0.2 \\
\hline & \begin{tabular}{|l|} 
Estonia \\
\end{tabular} & 2010 & 80.5 & 0.1 \\
\hline & \begin{tabular}{|l|} 
Estonia \\
\end{tabular} & 2018 & 89.9 & 0.1 \\
\hline & Finland & 2000 & 100.0 & 0.2 \\
\hline & \begin{tabular}{|l} 
Finland \\
\end{tabular} & 2010 & 98.1 & 0.2 \\
\hline & \begin{tabular}{|l|} 
Finland \\
\end{tabular} & 2018 & 100.0 & 0.1 \\
\hline & \begin{tabular}{|l|} 
France \\
\end{tabular} & 2000 & 89.3 & 0.2 \\
\hline & France & 2010 & 89.5 & 0.2 \\
\hline & France & 2018 & 88.0 & 0.1 \\
\hline & Germany & 2000 & 93.4 & 0.2 \\
\hline & Germany & 2010 & 93.3 & 0.2 \\
\hline & Germany & 2018 & 95.2 & 0.1 \\
\hline & Greece & 2000 & 75.1 & 0.2 \\
\hline & Greece & 2010 & 56.7 & 0.2 \\
\hline & Greece & 2018 & 55.8 & 0.1 \\
\hline & Ireland & 2000 & 90.4 & 0.2 \\
\hline & Ireland & 2010 & 92.9 & 0.2 \\
\hline & Ireland & 2018 & 90.9 & 0.2 \\
\hline & Italy & 2000 & 77.2 & 0.2 \\
\hline & Italy & 2010 & 61.9 & 0.2 \\
\hline & Italy & 2018 & 62.0 & 0.1 \\
\hline & Latvia & 2000 & 56.9 & 0.2 \\
\hline
\end{tabular}


Continued

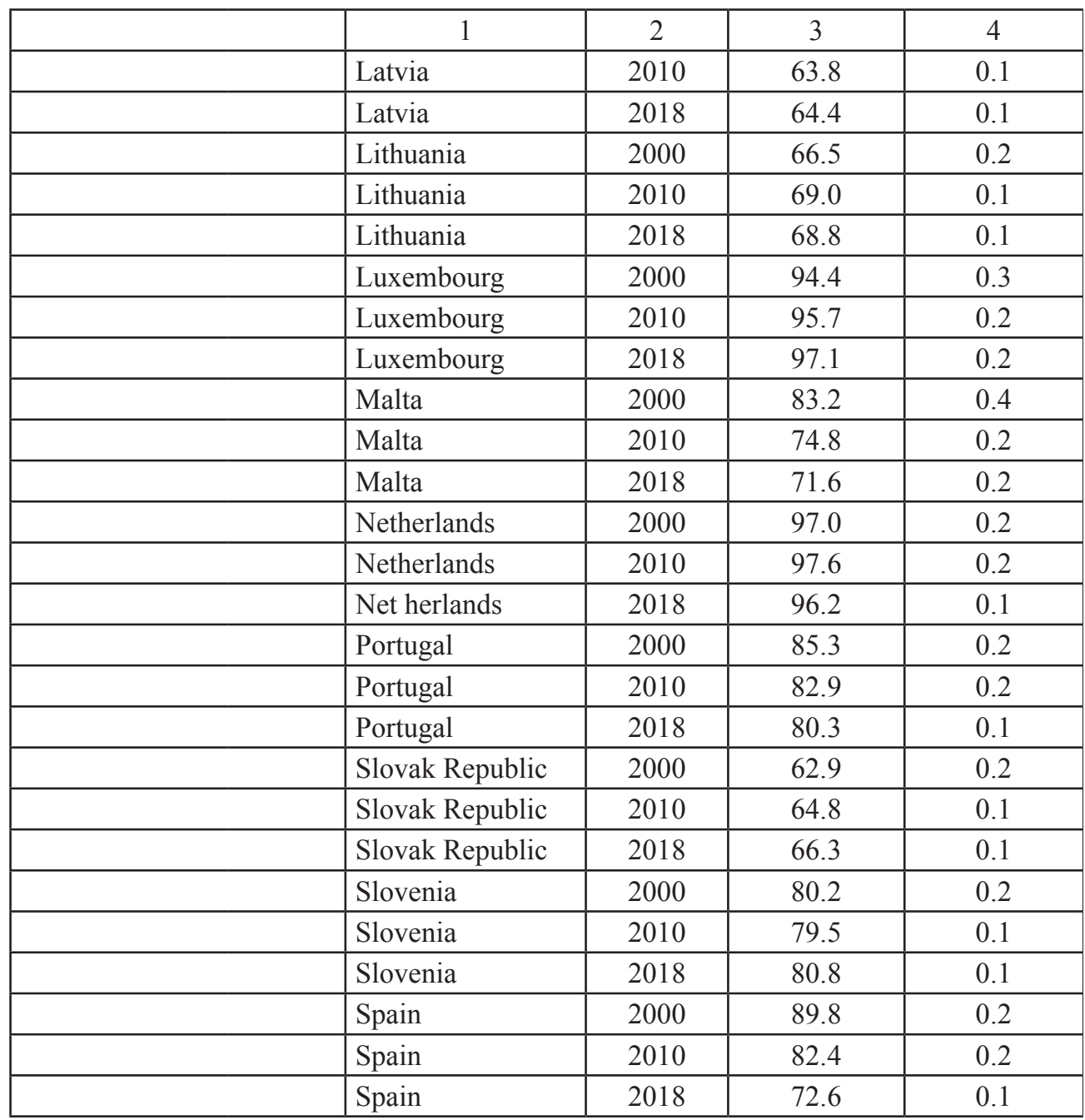

Source: World Bank (2020c) and own calculations

Corruption controls in the Euro zone are different. From the data in Table 6 we can trace the overall positive dynamics in a large part of the countries. At the beginning of the period, the best performing countries with regard to this indicator were Finland with a value of 100.0, Germany, Luxembourg, the Netherlands and Austria, whereas the worst performing ones were Lithuania, Slovakia, Latvia and Slovenia. At the end of 2018, the improvement or maintenance of the same values is found in the countries of the first group, and in the second there was improvement. There are several countries such as Greece, Cyprus and Italy that in 
the period between 2000 and 2018 showed a deteriorating performance. However, for the period under review, Bulgaria revealed its poorest ranking in both absolute and relative terms -53.8 for 2000 and 51.0 for 2018 . These data give reason to believe that there are signs of distancing from the Euro zone countries.

During the studied period, Bulgaria was moving away from the countries with low corruption levels, evidence for which is the Corruption Perceptions Index for 2019 , reaching 43 points. As a result our country dropped to $74^{\text {th }}$ position in world rankings. Within the regional ranking of the Member States of the European Union, Bulgaria continues to occupy the last position (the average value of the index is 64.32). The analysis of the results for the period up to 2019 gives reason to make a critical assessment - there is no significant progress in combating corruption. Furthermore, the positive developments in a significant number of EU Member States (such as Estonia, Czech Republic, Greece) exposes a trend of Bulgaria's falling behind. The data underlying the ranking show deficits in key areas such as political party funding and election campaigns; observance of democratic standards in the electoral process, freedom of the media; criteria for selection and appointment of persons to managerial positions in the institutions; effective investigation of corruption; lobbying; lack of effective participation of citizens in the consultation process related to political decision-making, etc.

When Bulgaria joined the EU in 2007, the EC set up a Co-operation and Verification Mechanism (SME) to help the country address shortcomings in the rule of law and focus on fighting corruption. At the end of 2019, the EU assessed relatively well Bulgaria's efforts and progress under this mechanism. The EU believed that the effect of the reforms will be felt at a later stage, and the country had yet to achieve concrete results in investigating and prosecuting high-level corruption. The report emphasizes the need that the anti-corruption framework should continue to improve and stakeholders should be involved in the implementation of the anti-corruption strategy and in the setting of future priorities. More generally, it is noted that institutions in this direction need to build public trust and gain a reputation for taking action with independence and professionalism.

In practice, the reforms of the common institutional framework for combating corruption that were carried out in the last two years in Bulgaria began to bear fruit. This applies in particular to the Anti-Corruption Act adopted in January 2018. A new anti-corruption agency was established, and amendments were made in 2017 to the Administration Act, which specify the regulations for the work of internal corruption, inspectorates, and the 2017 amendments to the Code of Criminal Procedure, which gave the specialized prosecutor's office and the specialized court for combating organized crime additional powers in the fight against corruption at the highest levels of government. 


\section{Ease of Doing Business}

In the ranking of countries, the World Bank uses the so-called indicator Ease of Doing Business, which last year was renamed to Distance to Frontier. Despite this change, the methodology remains the same. Its values are from 0 to $100 \%$, where the closest, i.e. best performance is accepted $100 \%$. In calculating the final rating, analysts take into account the performance of countries on 41 indicators, grouped in 10 sub-indicators - complexity of starting a business, obtaining a building permit, access and connection to the grid, property registration, access to credit, protection of minority shareholders rights, are taxes easily paid, cross-border trade, performance of contracts and settlement of business disputes, and recognition of insolvency.

The Ease of Doing Business Index ranks countries based on how favorable the regulatory environment is for business operations with stronger protection of property rights. High-ranking economies (1 to 20) have simpler and friendlier business regulations. As of 2019, the latest annual World Bank rating includes 190 countries. Based on the data for the Euro zone countries, it is possible to summarize the following: In the first year in which data are provided - 2006, the best ranked countries are Ireland, Finland, Lithuania and Estonia. In 2019, Finland, Luxembourg and Belgium dropped in the ranking, while Austria, Latvia and France improved their positions.

The worst performing countries for 2007 were Greece, Italy, Slovenia and Portugal and by 2019 they had all improved their ranking for Ease of Doing Business (Table 7).

Table 7: Ease of Doing Business Ranking

\begin{tabular}{|l|c|c|c|c|c|c|c|c|c|c|c|c|c|c|}
\hline Country & 2006 & 2007 & 2008 & 2009 & 2010 & 2011 & 2012 & 2013 & 2014 & 2015 & 2016 & 2017 & 2018 & 2019 \\
\hline 1 & 2 & 3 & 4 & 5 & 6 & 7 & 8 & 9 & 10 & 11 & 12 & 13 & 14 & 15 \\
\hline Austria & 32 & 30 & 25 & 27 & 28 & 32 & 32 & 29 & 30 & 21 & 21 & 19 & 22 & 26 \\
\hline Belgium & 18 & 20 & 19 & 19 & 22 & 25 & 28 & 33 & 36 & 42 & 43 & 42 & 52 & 45 \\
\hline Bulgaria & 62 & 54 & 46 & 45 & 44 & 51 & 59 & 66 & 58 & 38 & 38 & 39 & 50 & 59 \\
\hline Cyprus & N/A & N/A & N/A & N/A & 40 & 37 & 40 & 36 & 39 & 64 & 47 & 45 & 53 & 57 \\
\hline Estonia & 16 & 17 & 17 & 22 & 24 & 17 & 24 & 21 & 22 & 17 & 16 & 12 & 12 & 16 \\
\hline Finland & 13 & 14 & 13 & 14 & 16 & 13 & 11 & 11 & 12 & 9 & 10 & 13 & 13 & 17 \\
\hline France & 44 & 35 & 31 & 31 & 31 & 26 & 29 & 34 & 38 & 31 & 27 & 29 & 31 & 32 \\
\hline Germany & 19 & 21 & 20 & 25 & 25 & 22 & 19 & 20 & 21 & 14 & 15 & 17 & 20 & 24 \\
\hline Greece & 80 & 109 & 100 & 96 & 109 & 109 & 100 & 78 & 72 & 61 & 60 & 61 & 67 & 72 \\
\hline Ireland & 11 & 10 & 8 & 7 & 7 & 9 & 10 & 15 & 15 & 13 & 17 & 18 & 17 & 23 \\
\hline Italy & 70 & 82 & 53 & 65 & 78 & 80 & 87 & 73 & 65 & 56 & 45 & 50 & 46 & 51 \\
\hline
\end{tabular}




\section{Continued}

\begin{tabular}{|l|c|c|c|c|c|c|c|c|c|c|c|c|c|c|}
\hline \multicolumn{1}{|c|}{1} & 2 & 3 & 4 & 5 & 6 & 7 & 8 & 9 & 10 & 11 & 12 & 13 & 14 & 15 \\
\hline Latvia & 26 & 24 & 22 & 29 & 27 & 24 & 21 & 25 & 24 & 23 & 22 & 14 & 19 & 19 \\
\hline Lithuania & 15 & 16 & 26 & 28 & 26 & 23 & 27 & 27 & 17 & 24 & 20 & 21 & 16 & 14 \\
\hline Luxembourg & N/A & N/A & 42 & 50 & 64 & 45 & 50 & 56 & 60 & 59 & 61 & 59 & 63 & 66 \\
\hline Malta & N/A & N/A & N/A & N/A & N/A & N/A & N/A & 102 & 103 & 94 & 80 & 76 & 84 & 84 \\
\hline Netherlands & 24 & 22 & 21 & 26 & 30 & 30 & 31 & 31 & 28 & 27 & 28 & 28 & 32 & 36 \\
\hline Portugal & 42 & 40 & 37 & 48 & 48 & 31 & 30 & 30 & 31 & 25 & 23 & 25 & 29 & 34 \\
\hline $\begin{array}{l}\text { Slovak } \\
\text { Republic }\end{array}$ & 37 & 36 & 32 & 36 & 42 & 41 & 48 & 46 & 49 & 37 & 29 & 33 & 39 & 42 \\
\hline Slovenia & 63 & 61 & 55 & 54 & 53 & 42 & 37 & 35 & 33 & 51 & 29 & 30 & 37 & 40 \\
\hline Spain & 30 & 39 & 38 & 49 & 62 & 49 & 44 & 44 & 52 & 33 & 33 & 32 & 28 & 30 \\
\hline
\end{tabular}

Source: World Bank (2020a) and own calculations

In the period between 2006 and 2019, Bulgaria performed better - to the $59^{\text {th }}$ position among 190 economies in the ranking of Doing Business, prepared by the World Bank and measuring the conditions for doing business. Despite the improved assessment during the period, considering that in 2015 Bulgaria came $38^{\text {th }}$ in the ranking, our country is not among the leaders along the Ease of Doing Business indicator.

All these observations do give grounds to assume that there are signs of a rapprochement of Bulgaria with the Euro zone countries in terms of Ease of Doing Business. Rather, uncertainty can be commented on. This indicator, as it is known, includes several sub-indicators, which determine the degree to which the regulatory environment is favorable for business activity. In terms of the business environment, the situation remains adverse. Due to the slow pace of improvement and the lack of significant reforms, Bulgaria dropped from $50^{\text {th }}$ in 2017 to $61^{\text {st }}$ place in the ranking in terms of the regulatory environment for business development. Overall, the World Bank report assesses that, with a few exceptions, such as in the areas of "cross-border trade" and ,protection of the rights of minority shareholders", Bulgaria has space for improvement in most categories with regard to the protection of minority owners and in the contract performance sub-index. However, positions are being lost in important areas such as "starting a business" or "access to electricity". The report concludes that the protection of intellectual property rights is weak and obtaining "construction permits" is expensive and complicated. Labor and skills shortages and institutional shortcomings remain among the main obstacles to investments, and they all have a negative impact on the growth prospects of enterprises. With regard to the Ease of Doing Business and the situation of small and medium-sized enterprises (SMEs), it should be 
noted that the latter still face a number of difficulties. Bulgaria's results are lower than the EU average in the implementation of the Small Business Act. In most categories, the country lags behind, especially in the areas of "entrepreneurship" and "skills and innovation", it should also be mentioned that measures in support of SME policies also had only a limited effect. A positive result is the fact that according to the survey on business access to finance (SAFE) from 2019 (ECB, 2019), only $6 \%$ of SMEs identified financing as their biggest problem. This share halved compared to its levels in 2009 - 2013. The most popular sources of funding are still credit lines, leasing and bank loans. Bulgaria is actively using EU support to further improve funding. In terms of triggering GDP-related investments under the European Fund for Strategic Investments (EFSI), Bulgaria is among the best performing Member States. The total EFSI funding amounts to EUR 472 million and is expected to generate additional investments worth EUR 2.4 billion. Bulgaria is also one of the largest beneficiaries of the Small Business Act, which is a comprehensive framework for EU policy on small and mediumsized enterprises.

At the end, the following conclusions can be drawn from the data-based analysis of the seven indicators of institutional quality:

1. In terms of voice and accountability, or capturing the extent to which the country's citizens participate in the election of government and follow the policy pursued, as well as freedom of expression, association and media freedom, there are clear signs that Bulgaria is distancing from the Euro zone countries.

2. With regard to political stability and the absence of violence, represented by minimizing the likelihood of the government destabilizing through unconstitutional or violent means, including terrorism and others, the findings suggest the following: The dynamics in the period between 2000 and 2018 suggest that there are signs of Bulgaria's uncertain convergence with the countries of the Euro zone.

3. Regarding the government effectiveness, represented by achieving quality of public services, capacity of state institutions, independence from political pressure, quality of formulated policies, creation of a favorable context for private investments, etc. there is a positive trend in Bulgaria that can be interpreted a sign of rapprochement with the Euro zone countries.

4. In terms of regulatory quality, represented by the government's ability to formulate sound policies and regulations that allow and encourage the development of the private sector, thus establishing uniform rules for economic engagement, there is a positive trend in Bulgaria that can be interpreted a sign of rapprochement with the Euro zone countries.

5. With regard to the rule of law represented by the possibility of respecting the rule of law, taking into account in particular the quality of contract enforcement, 
property rights, the application of police and court rules, the current trend can be seen to some extent as a sign of Bulgaria's convergence with the Euro zone countries.

6. With regard to the control on corruption or the understanding that the stronger the control of corruption, the greater the likelihood for economic success, given that the latter is a function of effort and competence, not of connections and bribes, the data suggest that there are signs of Bulgaria's distancing from the Euro zone countries.

7. In terms of Ease of Doing Business, an indicator covering many aspects that determine the extent to which the regulatory environment is favorable for business activity - starting a business, registering property, obtaining credit, investor protection, paying taxes, cross-border trade, performance of contracts, insolvency decisions, etc. many observations were made. All of them give reason to suggest that there are signs of Bulgaria's rapprochement with the Euro zone countries, albeit with pronounced instability.

\section{Conclusion}

The processes of convergence and reduction of the differences of the Bulgarian economy with those of the Euro zone countries are related to the institutional quality and to the efficiency of economic regulations. Therefore, in order to achieve institutional convergence, it is necessary to reduce disparities, bringing institutions and regulations closer together and their gradual harmonization. This should be combined with a sound policy to address inconsistencies. To reveal the logic of such an assumption, the institutional quality was assessed and analyzed. A comprehensive understanding was proposed as a set of fundamental political, social and legal rules and policies that form the basis for production, exchange, distribution and consumption in the economy. In effect, appropriate tools were sought for to carry out an accurate and adequate study based on seven indicators of institutional quality, given the ongoing processes in the EU and the Euro zone. Thanks to the data and the performed analysis, the possible conclusion can be made that there has been institutional convergence in Bulgaria.

\section{References}

Европейска комисия. (2020а). Информационно табло на ЕС в областта на правосъдието за 2020 г.: по-нататъшно подобрение на ефективността и достьпността на правосъдните системи на ЕС, съчетано с намаляване на усещането за независимост на съдебната власт в някои държави членки Брюксел, (Evropeyska komisia, 2020, Informatsionno tablo na ES v oblastta na pravosadieto za 2020 g.: po-natatashno podobrenie na efektivnostta i dostapnostta na pravosadnitesistemi na ES, sachetano s namalyavane na 
useshtaneto za nezavisimost na sadebnata vlast $\mathrm{v}$ nyakoi darzhavi chlenki Bryuksel), available at: https://ec.europa.eu/commission/presscorner/detail/ bg/ip_20_1316 accesed: (accessed 4 June 2020)

Европейска комисия. (2020b). SWD (2020) 501/ Работен документ на службите на Комисията, Доклад за България за 2020 г., придружаващ съобщение на комисията до Европейския парламент, Европейския съвет, Съвета, Европейската централна банка и Еврогрупата, Брюксел, Европейски семестьр 2020 г.: оценка на напредъка в структурните реформи, предотвратяването и коригирането на макроикономическите дисбаланси и резултати от задълбочените прегледи в съответствие с Регламент (ЕС) № 1176/2011 \{COM(2020) 150\}, (Evropeiska komisiya, (2020), SWD (2020) 501/ Raboten dokument na sluzhbite na Komisiyata, Doklad za Bulgariya za 2020 g., pridruzhavasht saobshtenie na komisiyata do Evropeiskiya parlament, Evropeiskiya savet, Saveta, Evropeiskata tsentralna banka i Evrogrupata, Bryuksel, Evropeyski semestar 2020 g.: otsenka na napredaka $\mathrm{v}$ strukturnite reformi, predotvratyavaneto i korigiraneto na makroikonomicheskite disbalansi i rezultati ot zadalbochenite pregledi $\mathrm{v}$ saotvetstvie s Reglament (ES) No 1176/2011 $\{\mathrm{COM}(2020) 150\}$ ), available at: https://eur-lex.europa.eu/legal-content/BG/TXT/PDF/?uri=CELEX:52020SC050 $1 \&$ from $=\mathrm{EN}$ (accessed 1 November 2020)

Европейска комисия. (2020). 501/ Работен документ на службите на Комисията, Доклад за България за 2020 г. придружаващ съобщение на комисията до Европейския парламент, Европейския съвет, Съвета, Европейската централна банка и Еврогрупата, Брюксел, с. 60, (Evropeiska komisiya, 2020, 501/ Raboten dokument na sluzhbite na Komisiyata, Doklad za Bulgariya za 2020 g.pridruzhavasht saobshtenie na Komisiyata do Evropeiskiya parlament, Evropeiskiya savet, Saveta, Evropeiskata tsentralna banka i Evrogrupata, Bryuksel, s. 60), available at: https://ec.europa.eu/info/publications/2020european-semester-country-reports_en (accessed 1 November 2020)

Марикина, М. (2019). Институционалната конвергенция - теоретични основи и съществуващи емпирични изследвания, Икономически и социални алтернативи, бр. 2, с. 21-32. (Marikina, М., 2019, Institutsionalnata konvergentsiya - teoretichni osnovi i sushtestvuvashti empirichni izsledvaniya, Ikonomicheski i sotsialni alternativi, br. 2, s. 21-32).

Министерски съвет. (2010). Програма за по-добро регулиране 2010 - 2013 г. (актуализация), София. (Ministerki savet, 2010, Programa za po-dobro regulirane 2010 - 2013 g. (aktualizatsia), Sofia).

Оперативна Програма Иновации и Конкурентоспособност, документи, 2021 - 2027, (Operativna Programa Inovatsii i Konkurentosposobnost, dokumenti, 2021 - 2027), available at: https://opic.bg/public/uploads/2020/04/novprogramen-period-2021-2027-g-9.pdf (accessed 15 December 2020) 
Пелипась, И. (2017). Реальная, номинальная и институциональная конвергенция в странах ЕАЭС, Исследовательский центр ИПМ, WP/17/03. (Pelipas, I., 2017, Realynaya, nominalynaya i institutsionalynaya konvergentsia v stranah EAЭS, Issledovatelyskiy tsentr IPM, WP/17/03).

Boudreaux, C., Holcombe, R. (2015). Institutional Convergence, Working Paper, Florida State University.

Bruinshoofd, A. (2016). Institutional quality and economic performance, Rabo Research-Economic Research, Rabobank, Utrecht, [online] available at: $<$ https:// economics.rabobank.com/publications/2016/january/institutional\%2Dquality\% 2Dand\%2Deconomic\%2Dperformance/> (accessed 1 September 2021).

Easterly, W., King, R., Levine, R., and Rebelo, S. (1992). How Do National Policies Affect Long-Run Growth? A Research Agenda, World Bank Discussion Paper 164, Washington, DC: The World Bank.

Elert, N., Halvarsson, D. (2012). Economic Freedom and Institutional Convergence, Ratio Working Paper №196.

Eurostat. (2010). European System of National and Regional Accounts (ESA 2010), https://ec.europa.eu/eurostat/web/esa-2010 (accessed 11 November 2020)

Fabro, G., Aixalá, J. (2013). Do the Models of Institutional Quality Differ According to the Income Level of the Countries? The Case of the Low-Income Countries, Review of Public Economics 206(3), pp. 11-26.

Gruševaja, M., Pusch, T. (2015). Institutional Convergence of CEECs and its Connection to Growth and Cohesion, Paper No. 7.01., available at: http://www. grincoh.eu/media/serie_7_institutional_convergence/grincoh_wp7.01_grusevaja_pusch.pdf, (accessed 5 September 2021)

Hayek, F. (1937). Economics and Knowledge, Economica IV, New Series, Vol. 4, No. 13.

Iancu, A. (2009). Institutional Convergence, Romanian Academy the National Institute for Economic Research, Bucharest, Working Papers, No. 090101.

IMF. (2003). World Economic Outlook: Growth and Institutions, Washington: International Monetary Fund.

Kasper, W., Streit, M. (1998). Institutional Economics: Social Order and Public Policy, The Locke Institute, Edward Elgar, Cheltenham, UK.

Kaufmann, D., Kraay, A., Mastruzzi, M. (2013). The Worldwide Governance Indicators, (WGI) Project, World Bank. available at: http://info.worldbank. org/governance/wgi/index.aspx\#home, (accessed on 10/22/2013)

Kuncic, A. (2014). Institutional Quality Dataset, Journal of Institutional Economics, 10(1), pp. 135-161.

López-Tamayo, J., Ramos., R., Suriñach, J. (2014). An Institutional, Social and Economic Performance Index with an Application to the European Neighborhood Policy, Regional Quantitative Analysis Research Group Working Paper 2014/122/41. 
Liargovas, G., Fotopoulos G. (2009). Socioeconomic Indicators for Analyzing Convergence: The Case of Greece: 1960 - 2004, Social Indicators Research, 93(2), pp. 315-330.

Popescu, I. (2012). Institutional quality: criteria, determinants and benefits. in WSEAS, 1th International Conference on Economics, Political and Law Science: Advances in Economics, Risk Management, Political and Law Science. Zlin, Czech Republic, 20-22 September, Zlin: WSEAS Press, pp. 36-40, [online] available at: $<$ http:// www.gbv.de/dms/zbw/789436930.pdf $>$ (accessed 26 August 2021)

Prisecaru, P. (2008). Procesul de Convergență Instituțională, Editura Economică, București, Vol. I.

Raleva, S., Marikina, M. (2020). Structural Convergence with Eurozone and Institutional Quality in Bulgaria, 33rd EBES Conference, Spain, October 7-9, EBES Publications 33rd EBES Conference - Program and Abstract Book October, p. 586-600, available at: https://www.dropbox.com/sh/20nkoocxe8530us/ AABIERvFIU-DCplPmCI-ziqza/Proceedings?dl=0\&preview=33rd+EBES + Conference+Proceedings +-+ Vol+I.pdf\&subfolder_nav_trackin (accessed 9 September 2021).

Raluca, E. (2014). Social Economic Debates, Institutional Convergence - Part of Romania's Economic Development, Bucharest University of Economic Studies, Romania, Vol. 3, No. 1, April.

Rodríguez-Pose, A., Tselios V. (2013). Toward Inclusive Growth: Is There Regional Convergence in Social Welfare?, International Regional Science Review, forthcoming. http://dx.doi.org/10.1177/0160017613505201

Savoia, A., Sen, K. (2012). Do We See Convergence in Institutions? A Cross-Country Analysis, Development Economics and Public Policy Working Paper, No. 33.

Schönfelder, N. (2017). Institutional Convergence in Europe. Impact of European Integration. Hagen: Fern Universität Hagen, available at: http://nbn-resolving. de/urn:nbn:de:hbz:708-dh5633 (accessed 2 October 2020)

Schönfelder, N., Wagner, H. (2019). Institutional convergence in Europe, Economics: The Open-Access, Open-Assessment E-Journal, (13), 2019-3, http://dx.doi.org/10.5018/economics-ejournal.ja.2019-3.

World Bank. (2020a). Doing Business Data, available at: https://www.doingbusiness.org/en/data (accessed 12 January2021)

World bank. (2020b). Ease of doing business score and ease of doing business ranking, available at: https://openknowledge.worldbank.org/bitstream/hand le/10986/32436/9781464814402_Ch06.pdf

World Bank. (2020c). The World Governance indicators, available at: http://info. worldbank.org/governance/wgi/index.aspx\#reports (accessed 12 January 2021)

Wu, P., Fan, C., Pan, S. (2014). Does Human Development Index Provide Rational Development Rankings? Evidence from Efficiency Rankings in Super Efficiency Model, Social Indicators Research, 116 (2), pp. 647-658. 